\title{
BUTORPHANOL: A DOUBLE-BLIND EVALUATION IN POSTOPERATIVE PATIENTS WITH MODERATE OR SEVERE PAIN
}

\author{
Allen B. Dobkin, M.D., F.R.C.P.(C), 'Sooky Eamkaow, M.D., \\ Samuel Zak, m.d., and Frank S. Canuso, PH.D.†
}

\begin{abstract}
"Among the remedies which it has pleased Almighty God to give to man to relieve his sufferings, none is so universal and so efficacious as opium."
\end{abstract}

Thomas Sydenham, 1624-1689

THE ABOVE QUOTATION preceded the current serious American drug culture by some ten generations. Hallucinations, social withdrawal, dysphoria and other symptoms of opium addiction are now very well known and have become a frightening problem of our society. A possible shortage of potent analgesics is therefore not the main concern to the pharmaceutical industry and the clinical therapist. We must find new potent pain-relieving drugs that are not addicting. There is great urgency in this quest.

Following the Second World War, nalorphine was developed as a morphine antagonist, but Lasagna and Beecher found that it had strong analgesic properties as well. ${ }^{1}$ It caused respiratory depression and a high incidence of hallucinations which precluded extensive clinical evaluation as an analgesic. Subsequently, levallorphan was developed as an antinarcotic, but it was only effective for augmenting respiration in the presence of considerable narcotic-induced respiratory depression, and it also caused respiratory depression as well as dysphoria, drowsiness, miosis, nausea, pallor and hallucinations, when used as an agonist. More recently, naloxone has been added to the market of effective drugs that relieve respiratory depression due to the narcotic analgesics. This compound is an cssentially pure narcotic antagonist in that it does not possess the agonistic properties of morphine associated with nalorphine and levallorphan, which become manifest in the absence of prior narcotic administration. Naloxone has a shorter period of activity than most of the narcotic analgesics. Therefore, a patient who has taken an overdose of an analgesic must be observed closely for several hours when reversal therapy is employed. In addition, naloxone may cause nausea and vomiting when it must be given repeatedly."

After 1960, a series of drugs with a benzomorphan nucleus were developed. These had antinarcotic properties and were potent analgesics with a very low propensity to addiction, low abuse liability, and were essentially devoid of properties causing severe respiratory depression, constipation and urine retention. Unfortunately, cyclazocine, the most potent among these analgesics, caused halluci-

-Department of Anaesthesiology, State University of New York, Upstate Medical Center, State University Hospital, Syracuse, New York 13210.

$\nmid$ Bristol Laboratories, P.O. Box 657, Syracuse, New York 13201.

600

Canad. Anaesth. Soc. J., vol. 21, no. 6, November 1974 
<smiles>NC1CC23CCCCC12CN(C1CCC1)CCc1ccc(O)cc13</smiles>

BUTORPHANOL<smiles>CC(C)=CCN1CC2CCC1(C)c1cc(O)ccc1C2C</smiles>

PENTAZOCINE

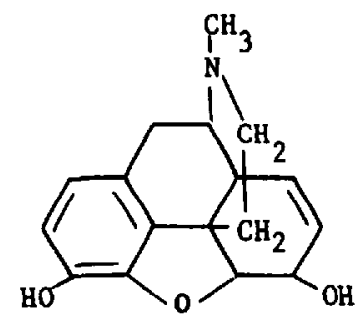

\section{MORPHINE}

Ficure 1. Structural formula of butorphanol compared with pentazocine and morphine.

nations; while pentazocine, which had fewer undesirable properties, was much less potent than morphine. ${ }^{3,4,5}$ Its efficacy in treatment of severe postoperative pain was somewhat limited because the dose required for good relief (40-60 $\mathrm{mg}$ ) caused excessive side-effects, and it was found to be much less efficacious than morphine, meperidine and fentanyl for balanced general anaesthesia because of the postoperative occurrence of nausea, vomiting, abdominal cramps and recall. ${ }^{\circ}$ Broad experience with pentazocine also showed that drug dependence and abuse occurs more frequently than was anticipated.

Butorphanol (levo BC-2627), shown in Figure 1, was synthesized by Bristol Laboratories of Canada. ${ }^{7.8}$ It is a totally synthetic narcotic antagonist analgesic which does not require opium alkaloids for its synthesis. In man the analgesic activity of butorphanol (expressed as weight of free base) appears to be ten times the potency of morphine sulfate and forty times that of pentazocine when injected intramuscularly. The duration of analgesic action appears similar to that of morphine. These findings agree with the preclinical pharmacological evaluation of butorphanol in animals ${ }^{9.10}$ which estimated the butorphanol analgesic potency as 4 to 10 times that of morphine sulfate and 25 to 70 times that of pentazocine. As a narcotic antagonist in animals, butorphanol is approximately equivalent in potency to nalorphine, 30 times that of pentazocine and $1 / 40$ that of naloxone.

Butorphanol physical dependence liability has been estimated to be low in animals. It precipitates withdrawal symptoms in morphine dependent mice and shows less suppression of withdrawal jumping than pentazocine in the withdrawn morphine dependent mouse. ${ }^{10}$ Also, butorphanol does not substitute for morphine in the withdrawn morphine dependent rhesus monkey. ${ }^{11}$ The evaluation of butor- 
phanol physical dependence in man is currently under investigation at the Addiction Research Center in Lexington, Kentucky.

In dogs, respiratory depression as evaluated by measuring arterial $\mathrm{PaCO}_{2}$ did not occur after an intravenous injection of $5 \mathrm{mg} / \mathrm{kg}$ of butorphanol. Doses of $1 \mathrm{mg} / \mathrm{kg}$ intravenously or $10 \mathrm{mg} / \mathrm{kg}$ orally did not produce any significant cardiovascular effects in dogs. Butorphanol was found to be one-tenth as potent as morphine in its effect on the gastrointestinal propulsive activity in mice. As an antitussive it is 20 times more potent than codeine in dogs, using electrical stimulation of the tracheal mucosa to induce coughing. ${ }^{12}$ Both the analgesic and antitussive activities of butorphanol are reversed by naloxone.

Rapid intravenous injection of $2 \mathrm{mg} / \mathrm{kg}$ morphine sulfate in beagle dogs causes sham rage and an elevated blood histamine level. In a crossover study, neither sham rage nor an elevated blood histamine occurred in the same dogs after the rapid intravenous injection of $0.5 \mathrm{mg} / \mathrm{kg}$ butorphanol. ${ }^{10}$

On the basis of the above data, butorphanol has been undergoing evaluation as an analgesic in patients with moderate to severe pain. In "open" evaluations, it appeared to be as effective as $10 \mathrm{mg}$ of morphine at a dose level of $1 \mathrm{mg}$. Doses higher than one milligram may produce lightheadedness and slight nausea and unsteady gait in normal volunteers. In patients with pain, only drowsiness has been noted as a side effect.

Our objective in this study was to evaluate the analgesic properties and the side-effects of butorphanol. This report deals with a double-blind evaluation of two corresponding dose levels each of butorphanol and morphine in patients who have had major surgical operations and complained of moderate to severe pain after recovering uakefulness from inhalation anaesthesia.

\section{Materials and Methods}

On the day preceding each study, several male and female patients were chosen from the surgical list according to the site and expected severity of the elective operation (usually major abdominal and major orthopedic procedures such as cholecystectomy and total hip replacement). Informed written consent was always obtained in the presence of an auditor witness (senior nurse or member of the patient's family). Minors, pregnant females, patients undergoing neurosurgery or cardiac surgery and those judged to have limited mental competence or who might have difficulty answering questions at interviews were excluded at the outset. Patients participating in other drug studies were also excluded, as were those with a history of drug tolerance or addiction to narcotic drugs, and patients with a history of overt or suspected renal, liver or haematological disease. A narcotic analgesic was not given for premedication unless the patient had preoperative pain. Diazepam or hydroxyzine with atropine was ordered for premedication. Inhalation anaesthesia with enflurane-nitrous oxide was selected in the majority of cases to avoid interference with the drug evaluations by persistence of analgesia due to the anaesthetic.

Bristol Laboratories prepared identical vials containing $1 \mathrm{ml}$ of solution. Of these, 30 contained $0.73 \mathrm{mgm}$ butorphanol tartrate ( $0.5 \mathrm{mgm}$ base) and an equal 
number contained $1.46 \mathrm{mg}$ butorphanol tartrate ( $1 \mathrm{mg}$ of base), $5 \mathrm{mgm}$ morphine sulphate and $10 \mathrm{mgm}$ morphine sulphate. The vials were numbered consecutively from 1 to 120 according to a random number table. As each consenting patient complained of pain after recovery from anaesthesia the degree of pain was determined by asking the site and its severity (slight-mild, moderate or severe). If the pain was described as moderate or severe and the patient again consented to relief with medication, admission to the study was initiated with a single intramuscular injection of the numbered medication in consecutive order of the random assignment. The patient was then kept under direct surveillance for at least two hours. Blood pressure, pulse rate, tidal volume, respiratory rate and other vital signs were measured and recorded as necessary. A record of pain complaints was kept on the recovery room chart. A pain score, a pain relief score, and any side-effects of the medication given were recorded on the study protocol at 30 , 60 and 120 minutes. After the end of an additional three hours, and again the next day, the nurses' notes were reviewed to determine whether the patients requested and received further medication for relief of pain. These data were also entered on the patient's protocol.

Pain intensity was scored numerically as 3 (severe), 2 (moderate) and 1 (mild). Pain relief was scored: 0 (no relief), 1 (slight relief), 2 (moderate relief, 3 (good relief) and 4 (complete relief). A pain intensity difference (PID) score was calculated by subtracting the pain intensity at each time-interval from the initial pain score. During the two-hour post-medication period, each patient was encouraged not to request additional analgesic medication unless severe pain resumed. All additional analgesic medication was recorded on the protocol up to five hours after initiation of each study. At the conclusion of the study, all the information was tabulated, the code was revealed, and the data were analyzed statistically. The parameters of interest (summed scores over the twohour observation period) were analyzed by the parallel-line assay method described by Finney ${ }^{13}$ employing a modification of the computer program he developed. ${ }^{14}$ This analysis encompassed variance analyses, linear dose-response regressions and estimation of butorphanol potency relative to morphine.

\section{Results}

Informed consent for postoperative pain medication was obtained from over 350 patients, of whom 120 complained of moderate to severe pain and requested medication. Most studies were initiated within one hour after the patient reached the recovery room. The majority of the patients $(>110)$ had been premedicated with diazepam with atropine and received enflurane- $\mathrm{N}_{2} \mathrm{O}$ or halothane- $\mathrm{N}_{2} \mathrm{O}$ anaesthesia.

The vital data for each of the patients are summarized in Table I. Ten subjects required additional analgesia before completion of the initial two-hour observation period. In these instances subsequent pain scores were adjusted to 3 (severe) and pain relief scores to zero (no relief). One patient appeared twice (No. 56 and No. 103) having received $5 \mathrm{mg}$ and $10 \mathrm{mg}$ morphine respectively. Two patients were removed from the statistical analysis: one (No. 61, who received 


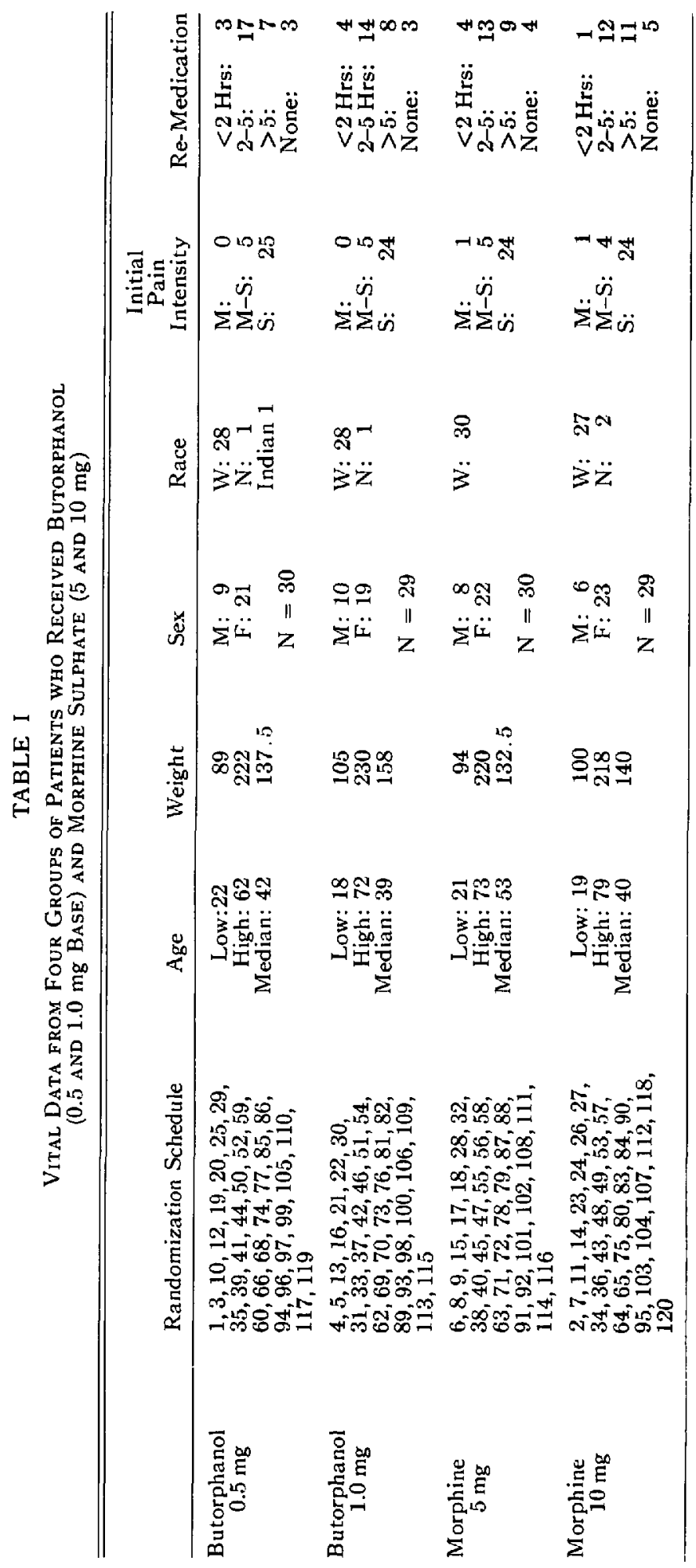


DOBKIN, et al.: BUTORPHANOL: A DOUBLE-BLIND EVALUATION

TABLE II

Summary of Mean Pain Scores in the 4 Groups of Patients

\begin{tabular}{|c|c|c|c|c|c|c|c|c|c|}
\hline & \multirow[b]{3}{*}{ Hrs. } & \multicolumn{4}{|c|}{ Butorphanol } & \multicolumn{4}{|c|}{ Morphine } \\
\hline & & \multicolumn{2}{|c|}{$0.5 \mathrm{mg}$} & \multicolumn{2}{|c|}{$1.0 \mathrm{mg}$} & \multicolumn{2}{|c|}{$5 \mathrm{mg}$} & \multicolumn{2}{|c|}{$10 \mathrm{mg}$} \\
\hline & & Mean & S.E. & Mean & S.E. & Mean & S.E. & Mean & S.E. \\
\hline Pain & $\begin{array}{l}0 \\
\frac{1}{2} \\
1 \\
2\end{array}$ & $\begin{array}{l}3.00 \\
1.17 \\
0.90 \\
1.10\end{array}$ & $\begin{array}{l}0 \\
0.18 \\
0.19 \\
0.21\end{array}$ & $\begin{array}{l}3.00 \\
0.69 \\
0.83 \\
1.24\end{array}$ & $\begin{array}{l}0 \\
0.17 \\
0.19 \\
0.19\end{array}$ & $\begin{array}{l}2.97 \\
1.33 \\
1.13 \\
1.50\end{array}$ & $\begin{array}{l}0.03 \\
0.18 \\
0.21 \\
0.23\end{array}$ & $\begin{array}{l}2.97 \\
0.97 \\
0.59 \\
0.86\end{array}$ & $\begin{array}{l}0.03 \\
0.19 \\
0.19 \\
0.21\end{array}$ \\
\hline & Total & 6.17 & 0.50 & 5.76 & 0.51 & 6.93 & 0.56 & 5.38 & 0.52 \\
\hline Pid & $\begin{array}{l}\frac{1}{3} \\
1 \\
2\end{array}$ & $\begin{array}{l}1.83 \\
2.10 \\
1.90\end{array}$ & $\begin{array}{l}0.18 \\
0.19 \\
0.21\end{array}$ & $\begin{array}{l}2.31 \\
2.17 \\
1.76\end{array}$ & $\begin{array}{l}0.17 \\
0.19 \\
0.19\end{array}$ & $\begin{array}{l}1.63 \\
1.83 \\
1.47\end{array}$ & $\begin{array}{l}0.18 \\
0.21 \\
0.23\end{array}$ & $\begin{array}{l}2.00 \\
2.38 \\
2.10\end{array}$ & $\begin{array}{l}0.19 \\
0.19 \\
0.21\end{array}$ \\
\hline & Total & 5.83 & 0.50 & 6.24 & 0.51 & 4.93 & 0.57 & 6.48 & 0.51 \\
\hline Relief & $\begin{array}{l}\frac{1}{3} \\
1 \\
2\end{array}$ & $\begin{array}{l}2.63 \\
2.90 \\
2.70\end{array}$ & $\begin{array}{l}0.23 \\
0.24 \\
0.28\end{array}$ & $\begin{array}{l}3.17 \\
3.10 \\
2.59\end{array}$ & $\begin{array}{l}0.19 \\
0.21 \\
0.26\end{array}$ & $\begin{array}{l}2.57 \\
2.70 \\
2.33\end{array}$ & $\begin{array}{l}0.22 \\
0.26 \\
0.27\end{array}$ & $\begin{array}{l}2.97 \\
3.31 \\
3.07\end{array}$ & $\begin{array}{l}0.20 \\
0.21 \\
0.23\end{array}$ \\
\hline & Total & 8.23 & 0.65 & 8.86 & 0.61 & 7.60 & 0.71 & 9.34 & 0.54 \\
\hline
\end{tabular}

$1 \mathrm{mg}$ butorphanol) had received meperidine intravenously at the end of the operation and one (No. 67, who received $10 \mathrm{mg}$ morphine) had received prochlorperazine to relieve marked nausea and vomiting during the initial two-hour observation period. Three of the four groups were very well matched in all respects. The group of patients that received butorphanol $1 \mathrm{mg}$ happened to have a significantly greater mean body weight and had more male patients than in the other three groups.

The blood pressure and pulse rate varied after analgesic medication, with a general trend to a small reduction in systolic blood pressure and pulse rate, but the changes appeared not to be significant. No patient developed evident respiratory depression euphoria or hallucinations after any of the medications. Substantial pain relief was seen in most instances at the 30 minutes observation period. Approximately 90 per cent of all of these patients required no further medication within two hours of the study drug.

Means and standard errors for pain intensity, pain intensity difference (PID) and pain relief scores, by drug group for each observation point and total, are listed in Table II, with graphical representation in Figures 2 and 3.

Observe that the response to $1 \mathrm{mg}$ butorphanol was of somewhat briefer duration than with the smaller dose. However, the responses were subject to the usual psychic and physiological variations seen among patients, which could markedly influence the assigned mathematical scores in a relatively small group even if only a small number of patients said they had mild pain instead of moderate pain! As noted before, there was also an uneven proportion of male to female patients in this group compared to the other three groups, with a corresponding greater mean body weight. All of these chance factors could explain the discrepant scores at the second hour, resulting in overlapping standard error of the means, 

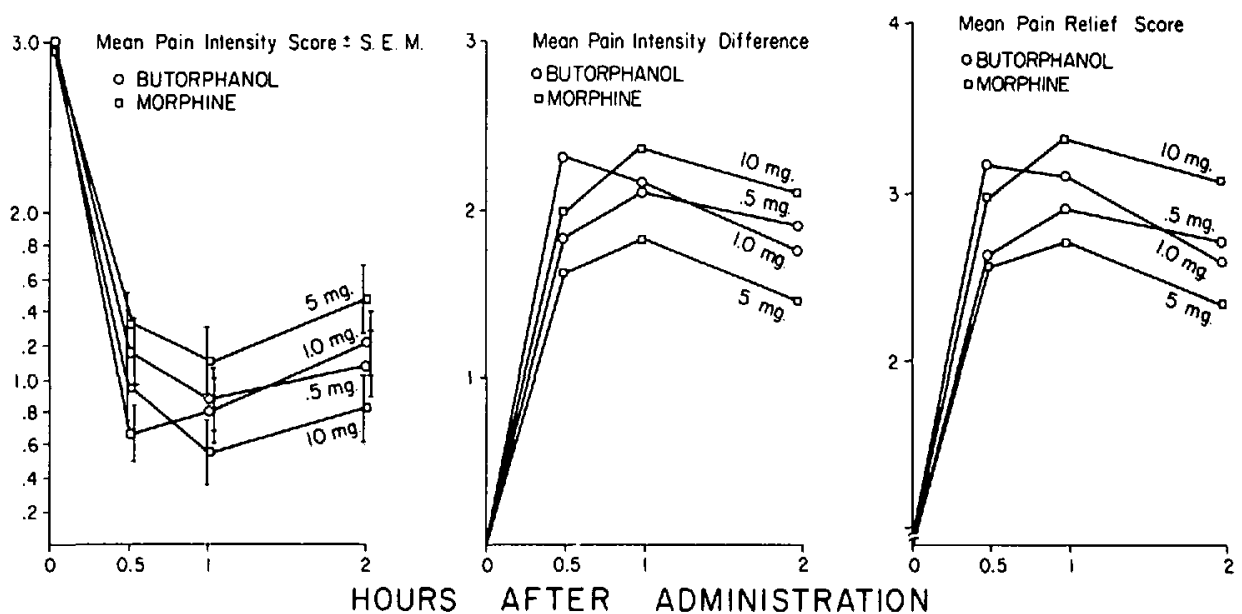

Frcure 2, This is the graphical representation of pain intensity, pain difference and pain relief scores in response to administration of butorphanol (base) and morphine (sulfate) in this study. Observe that the two doses of butorphanol ( 0.5 and $1.0 \mathrm{mg}$ base) appear to be indistinguishable but their analgesic effect is comparable to 5 to $10 \mathrm{mg}$ of morphine sulphate.

\section{DOSE-RESPONSE DIAGRAMS Mean Response Vs. Dose Metameter}
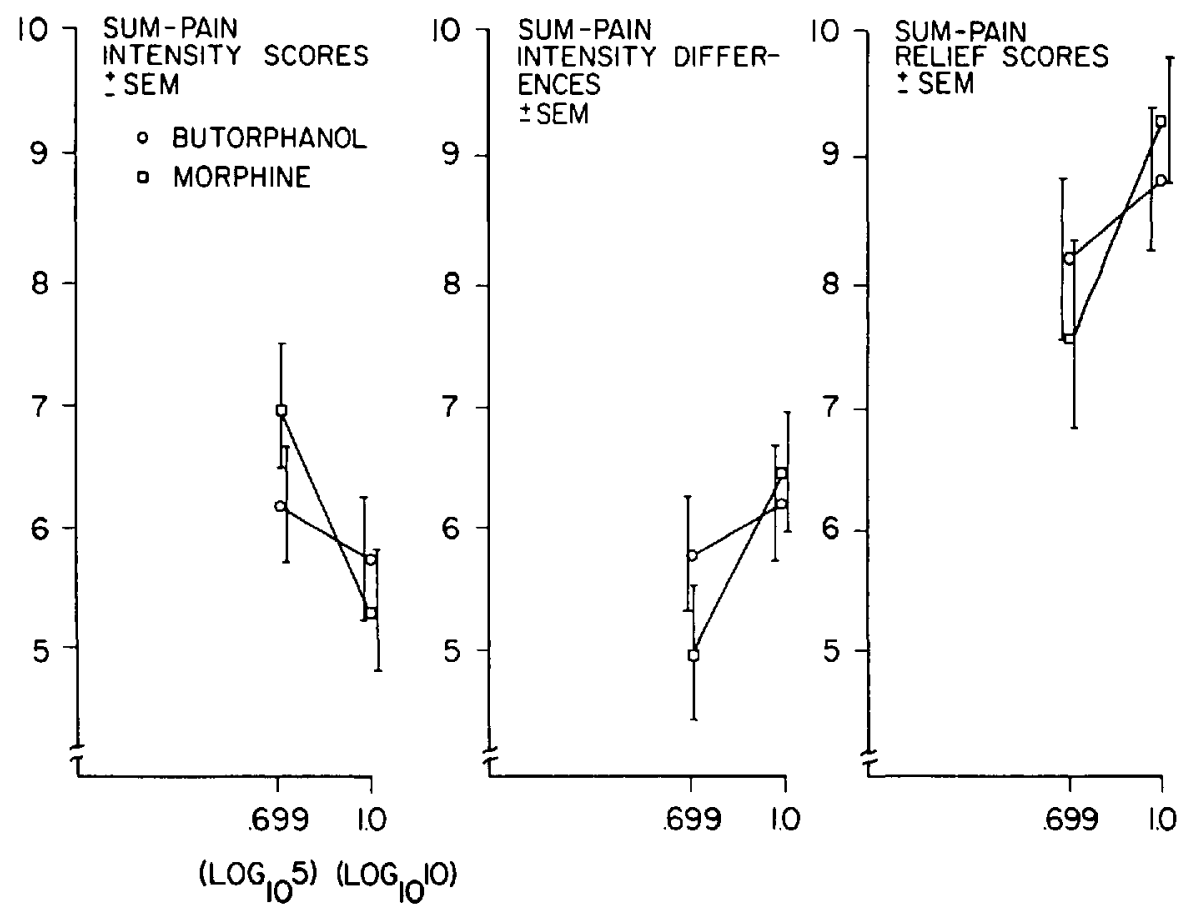

Ficure 3. This is the graphical representation of the sum of the pain scores, which again indicate that the effect of butorphanol (base) and morphine (sulphate) are closely comparable in the doses tested. 
DOBKIN, et al.: BUTORPHANOL: A DOUBLE-BLIND EVALUATION

TABLE III

\begin{tabular}{|c|c|c|c|c|}
\hline & Side Effect & $\frac{1}{2} \mathrm{Hr}$ & $1 \mathrm{Hr}$ & $2 \mathrm{Hrs}$ \\
\hline $\begin{array}{c}\text { Butorphanol } \\
0.5 \mathrm{mg}\end{array}$ & $\begin{array}{l}\text { Drowsy/Sleepy } \\
\text { Asleep } \\
\text { Dizzy } \\
\text { Nausea } \\
\text { Cramps and Nausea }\end{array}$ & $\begin{array}{l}7 \\
2 \\
1 \\
1 \\
-\end{array}$ & $\begin{array}{r}11 \\
3 \\
- \\
-\end{array}$ & $\frac{8}{1}$ \\
\hline $\begin{array}{c}\text { Butorphanol } \\
1.0 \mathrm{mg}\end{array}$ & $\begin{array}{l}\text { Drowsy/Sleepy } \\
\text { Asleep } \\
\text { Dizzy } \\
\text { Nausea }\end{array}$ & $\frac{14}{1}$ & $\frac{12}{-}$ & $\frac{10}{-}$ \\
\hline $\begin{array}{l}\text { Morphine } \\
10 \mathrm{mg}\end{array}$ & $\begin{array}{l}\text { Drowsy/Sleepy } \\
\text { Asleep } \\
\text { Nausea } \\
\text { Emesis }\end{array}$ & $\begin{array}{c}5 \\
2 \\
1\end{array}$ & $\frac{9}{2}$ & $\frac{6}{2^{*}}$ \\
\hline $\begin{array}{l}\text { Morphine } \\
10 \mathrm{mg}\end{array}$ & $\begin{array}{l}\text { Drowsy/Sleepy } \\
\text { Asleep } \\
\text { Nausea } \\
\text { Cramps and Nausea }\end{array}$ & $\frac{8}{1}$ & $\begin{array}{r}11 \\
1 \\
1 \\
-\end{array}$ & $\begin{array}{r}2 \\
1 \\
1\end{array}$ \\
\hline
\end{tabular}

*1 after additional medication.

and rendering the two butorphanol dose levels clinically indistinguishable. According to the computer analysis, the estimated relative potency of butorphanol base was determined to be of the order of ten times that of morphine. In terms of the salts, the ratio was approximately $7: 1$.

Side-effects are listed in Table III. The only significant effect of both medications, besides analgesia, was the development of drowsiness. This occurred oftener, earlier and persisted longer with butorphanol than with morphine; such differences, however, were not statistically significant. The occurrence of other side-effects was negligible.

Based on the observations, butorphanol appeared to be a satisfactory and safe drug for postoperative relief of pain.

\section{Discussion}

The evaluation of pain and its relief is one of the most difficult judgments that has to be made in therapy. ${ }^{15}$ The factors that influence the occurrence and intensity of pain after surgery and anaesthesia are numerous, including mainly the psychic attitude of the patient toward his disease, the site and extent of the surgical wound and the degree of manipulation of organs rich in sensory fibers. ${ }^{16}$

The analgesic potency and duration of action of the anaesthetic used, as well as the amount of sedative drugs given previously, also have a significant influence on the overt response to pain. Exogenous factors( environmental), as well as the age and sex of the patient, also play a role. Elderly patients and females generally do not require much analgesic medication. Lasagna and associates have reported on the high incidence of "placebo reactors" - as high as 45 per cent. These were patients who admitted relief of pain after receiving only a saline injection. ${ }^{17}$ 
Papper and associates showed that as many as 30 per cent of surgical patients do not complain of any pain after major surgery. ${ }^{18}$ Of the remainder in his study, about half the patients complained of moderate to severe pain and the rest had pain that was easily relieved by infrequent doses of narcotic analgesics. Therefore, it appears that only about one-third of patients who have undergone major surgery request or need at least one injection of a potent analgesic. These responses make it difficult to determine the efficacy of analgesic drugs until a large number of dose-effect observations have been made under carefully controlled conditions.

In this double-blind study it was evident once again that only about one-third of patients who have undergone major surgery have, or complain of, severe pain postoperatively and desire medication for its relief. It is evident that analgesic medication with 0.5 or $1.0 \mathrm{mg}$ butorphanol given in the early postoperative period in response to a patient's complaint of moderate to severe pain, provides relief comparable to that obtained with 5 or $10 \mathrm{mg}$ morphine given intramuscularly. As noted, the analgesic action of each drug was evident at the 30-minute observation period and, in 90 per cent of the patients, analgesia lasted at least two hours. Aside from drowsiness, the incidence of side-effects with butorphanol was negligible. In postanaesthetic care of patients who have had major surgery these properties of butorphanol are eminently acceptable. ${ }^{19,20}$ The safety and efficacy of the now compound therefore appears to be highly probable. If accumulation of a large number of case studies establishes that butorphanol is indeed nonaddicting, is not subject to abuse, and lacks appreciable respiratory or circulatory depressant properties, it will be an appropriate addition to our analgesic drug armamentarium.

\section{Summary and Conclusions}

Informed consent was obtained from over 350 patients scheduled for major elective operations to accept either 5 or $10 \mathrm{mg}$ morphine or 0.5 or $1.0 \mathrm{mg}$ butorphanol (intramuscularly) under double-blind conditions according to a random assignment schedule, if they should complain of moderate to severe pain while in the recovery room. Of those consenting, 120 patients were entered in the study. The remainder either denied any pain, stated that they had only slight or mild pain, or in a few instances, refused analgesic medication although they stated they had more than mild pain. Pain intensity and pain relief were scored for each treated patient at 30,60 and 120 minutes. Scores were analyzed statistically after tabulating the data. The data show that in virtually all these patients appreciable pain relief was admitted at the first observation period ( 30 minutes after administration of the drug) and it persisted for at least two hours in 90 per cent of them. No consistent alteration in the vital signs (blood pressure, pulse rate, rate of respiration or tidal volume) was evident in these patients during the two hours they were kept under close surveillance. Approximately 10 per cent of the patients receiving butorphanol, and 15 per cent of those receiving morphine, did not request more analgesic medication; 52 per cent (butorphanol) and 42 per cent (morphine) respectively requested additional medication two to five hours after, 
and 25 per cent (butorphanol) and 34 per cent (morphine), respectively, requested it only after 5 hours. Analysis by the parallel line assay method produced an estimate that butorphanol (base weight) was on the order of ten times more potent than morphine sulfate. Due to uncertain factors, the effect of the two doses of butorphanol tested could not be distinguished two hours after medication.

Drowsiness occurred early in one-third of the patients receiving butorphanol and usually persisted for several hours, whereas this effect was less prominent with morphine and was of shorter duration. Dizziness, nausea or emesis occurred in less than 5 per cent after either medication. If extensive experience with butorphanol shows that it is non-addicting and does not cause appreciable respiratory depression, it will indeed be a useful analgesic drug.

\section{RÉSUMÉ}

Nous avons au préalable, obtenu la permission de 350 malades subissant une chirurgie élective majeure, de les inclure dans une étude comparative de deux analgésiques soit le Butorphanol et la Morphine. Ils avaient accepté de recevoir l'un ou l'autre de ces médicaments en cas de douleur modérée ou importante, dans la salle de réveil, tout ceci dans le cadre d'une étude à double-insu. Les doses a.dministrées étaient de 5 à $10 \mathrm{mg}$ de Morphine ou de $0.5 \mathrm{mg}$ à $1 \mathrm{mg}$ de Butorphanol.

De ces 350 malades, 120 furent effectivement étudiés, ayant reçu l'un ou l'autre des médicaments à l'étude. Les autres n'ont pas présenté de douleur ou n'ont accusé qu'une douleur légère ou encore ont refusé un calmant tout en admettant une douleur plus que légère.

Chez tous ceux ayant reçu l'un ou l'autre des analgésiques, l'intensité de la douleur et l'efficacité de son soulagement fut notée 30,60 et 120 minutes après l'administration du médicament. Les résultats ont démontré dans pratiquement tous les cas qu'il y avait soulagement appréciable de la douleur trente minutes après l'administration de l'un ou l'autre des agents et que cette analgésie persistait au moins 2 heures chez 90 pour cent d'entre eux. Pendant cette même période de 2 heures, les signes vitaux demeurèrent stables (fréquence cardiaque, pression artérielle, fréquence + amplitude de la respiration).

Environ 10 pour cent de ceux qui reçurent du Butorphanol et 15 pour cent de ceux ayant reçu de la Morphine n'ont pas requis d'autre analgésique; 52 pour cent des patients ayant reçu du Butorphanol et 42 pour cent des sujets à la Morphine ont requis une dose additionnelle de médicament entre 2 et 5 heures après.

Enfin, 259 des malades ayant reçu du Butorphanol et 34 pour cent de ceux ayant reçu de la Morphine ont requis une dose supplémentaire plus de 5 heures après la première administration. On estime que, poids pour poids, le Butorphanol est 10 fois plus puissant que la Morphine. Deux heures après l'administration on ne pouvait faire de distinction entre les effets des deux dosages de Butorphanol utilisés. Chez environ 1/3 des patients, le Butorphanol produit de la somnolence, effet qui persiste quelques heures et semble plus marqué et plus prolongé, qu'avec la Morphine. Moins de 5 pour cent malades des deux séries ont présenté des étourdissements, des nausées et des vomissements. 
Si à l'usage, le Butorphanol ne montre pas de propriétés addictives et ne cause pas de dépression respiratoire importante, ce sera un médicament utile.

\section{ACKNOWLEDGMENTS}

The authors are grateful to the nursing staff in the recovery room for their assistance, care and attention to details during this study, to Judith D. Simonds, R.N. and Barbara Esposito, R.N. for assisting with follow-up of the patients and analysis of clinical data, and to R.D. Wilkins for the comprehensive computer analyses of the scores.

\section{REFERENCES}

1. Lasagna, L. \& Beecher, H.K. The analgesic effectiveness of nalorphine and nalorphinemorphine combinations in man. J. Pharmacol. Exp. Ther. 112: 356 (1954).

2. Longnecker, D.E., Grazis, P.A., \& Eggens, G.W.N. Naloxone for antagonism of morphine-induced respiratory depression. Anaesth. \& Analg. 52: 447 (1973).

3. Harris, L.S. \& Pierson, A.K. Some narcotic antagonists in the benzomorphan series. J. Pharmacol. Exp. Ther. 143: 141 (1964).

4. Gordon, R.A. \& Morgan, J.H. Studies of pentazocine (WIN 20,228). 1. Evaluation as an analgesic in post-operative patients. Can. Anaesth. Soc. J. 12: 331 (1965).

5. Jasinski, D.R., Mantin, W.R., \& Hoeldtke, R.D. Effect of short- and long-term administration of pentazocine in man. Clin, Pharm. \& Ther. 11: 385 (1970).

6. Dobkin, A.B., Israel, J.S., \& Pieloch, P.A. The metabolic response to pentazocine as a supplement to balanced anaesthesia for major abdominal surgery. Can. Anaesth. Soc. J. 17: 485 (1970).

7. Monkovic, I. Synthetic 14-hydroxymorphinan narcotic antagonists. Abstracts of 13th National Medicinal Chemistry Symposium, ACS Div. Med. Chem., Iowa City, Iowa (1972).

8. Monkovic, I., Conway, T.T., Wang, H., Perron, Y.G., Pachter, I.J., \& Belleau, B. Total synthesis and pharmacological activities of $\mathrm{N}$-substituted 3,14-dihydroxymorphinans. J. Am. Chem. Soc. 95: 7910 (1973).

9. Cordon, M., Pircio, A.W., Caruso, F.S., \& Pachter, I.J. Approaches to the problem of opiate abuse. Report of the Committee on Problems of Drug Dependence, 1974.

10. Pircio, A.W., Gylys, J.A., Cavanagh, R.L., \& Bierwagen, M.E. Pharmacology of butorphanol, a new potent antagonist analgetic agent. To be published.

11. Swain, H.H., Villarreal, J.E., \& Seevers, M.H. Evaluation of new compounds for morphine-like physical dependence in the Rhesus monkey. Report of the Committee on Problems of Drug Dependence, Addendum pp. 695, 696 (1973).

12. Cavanach, R.L., Gylys, J.A., \& Bienwagen, M.E. Antitussive properties of levo-Ncyclobutylmethyl-3,14 $\beta$-dihydroxymorphinan (Butorphanol). Pharmacologist (1974).

13. Finney, D.J. Statistical method in biological assay. New York, Hafner Publishing Co., 2nd ed. (1964).

14. McArthur, J.W., Ulfelder, H., \& FinNey, D.J. A flexible computer program for the composite analysis of symmetrical and asymmetrical biological assays of parallel-line type. J. Pharmacol. Exp. Ther. 153: 573 (1966).

15. Beecher, H.K. Measurement of subjective responses, New York, Oxford University Press (1959).

16. Foldes, F.F., Swerdlow, M., \& Siker, E.S. Narcotic and narcotic antagonists. Springfield, Charles C. Thomas (1964).

17. Lasagna, L., Mosteller, F., von Felsinger, J.M., \& Beecher, H.K. A study of the placebo response. Am. J. Med, 16: 770 (1954).

18. Papper, E.M., Brodie, B.B., \& Rovenstine, E.A. Postoperative pain: its use in the comparative evaluation of analgesics. Surgery 32: 107 (1952).

19. Eckenhoff, J. \& Оесн, S.R. The effects of narcotics and antagonists upon respiration and circulation in man. A review. Clin. Pharm. and Ther. I: 483 (1960).

20. Dobkin, A.B. \& Criswick, V.C. Circulatory response to tilt with narcotic analgesics in normal healthy male subjects. Anesthesiology 22: 398 (1961). 